\title{
MAPPING THE POTENTIAL OF THE OLD CITY TOURISM (Study of the History, Region and Cultural Value of the Old City on Bangka Island)
}

\author{
Jamilah Chollilah \\ ela.hasyim@yahoo.com \\ Herdiyanti \\ vhie_dyan@yahoo.co.id \\ Nurvita Wijayanti \\ wijayavita88@gmail.com \\ Novendra Hidayat \\ novendra.hidayat@yahoo.co.id \\ University of Bangka Belitung \\ Pangkalpinang, Bangka Belitung Archipelago, Indonesia
}

\begin{abstract}
This research is entitled Mapping the Tourism Potential of the Old City (Study of the History, Region and Cultural Value of the Old City on Bangka Island). The research objective was to map the tourism potential of the old city in Bangka Island, namely Belinyu and Muntok Districts. Overview this social mapping is divided into three aspects which include history, territory and cultural values. The problems in this study are formulated in three main questions, namely (1) How is the distribution of the old cities of Muntok and Belinyu based on Chinese, Malay and European clusters? (2) How does the distribution of the Chinese, Malay and European clusters affect the tourism promotion of the old city in Muntok and Belinyu? (3) How does Toponimi affect the tourism promotion of old cities in Muntok and Belinyu?The location of the study was conducted in Belinyu and Muntok Districts. The consideration is based on the search results of secondary data showing that these two regions were formerly known as the central areas of the Dutch colonial government (Muntok) and the center of tin mining activities (Belinyu). The research method used is descriptive qualitative research with social mapping techniques. Sources of data in this study include primary and secondary data. Primary data is obtained by means of interviews and direct observation from the speakers. Secondary data was obtained from reference books, research journals, and references through the internet that were related to the tourism potential of the old city.
\end{abstract}

Keywords: Old City Potential, Social Mapping, Local Herritage

\section{INTRODUCTION}

The old city which is in the structuring stage is also in the Province of Bangka Belitung Islands. Bangka Belitung besides being one of the regions that is famous for the largest tin mining sector in Indonesia, it is also one of the provinces that has a diversity of cultures. In Bangka Belitung there are several Old Cities including Muntok and Belinyu. The old city is one of the most important historical parts of the establishment of Bangka Island. Each of these old cities has its own characteristics and uniqueness both in terms of history, region, culture and language. 
BERUMPUN

P-ISSN 2622-8831

Berumpun Journal: An International Journal of Social, Politics and Humanities Vol. 2 No. 1 March 2019

Belinyu has a connection with the history of the Dutch colonial era at that time. Belinyu has a track record that greatly contributes to the city's progress. In Belinyu Subdistrict, historical places such as Benteng and Kuto Panji Temple, Gedong House, Fuk Tet Che Temple, Goa Maria, Malay architectural houses, Klangeng Phang Khak Liang and historical buildings are currently used as official houses of PT Timah, Kecamatan Belinyu is filled with tall buildings which turned out to be deliberately left for nest wallet activities, not only that the buildings in Belinyu are still original and traditional with the architectural style of the old buildings and gave rise to a collective memory of the history of Belinyu District.

This condition makes researchers interested that the old city has the potential and value of tourism if it is able to be developed both from the aspects of history, culture and architecture of buildings that characterize the city. Identification of potential through social mapping techniques is the main goal in identifying the extent to which the old city has the potential to be developed as the old city tourism. The role of the government also contributes to supporting the development of the potential of the old city in a sustainable manner. One of the efforts made by the Regional Government of Muntok was the promotion of the city of Muntok to the Netherlands. This effort is a step of synergy in maintaining the local cultural identity inherent in the old city. Synergy between the government and the community is needed in order to introduce the tourism potential of the city to other countries as tourism assets that have selling value. The purpose of this study was to determine the distribution of Muntok and Belinyu City based on Chinese, Malay and European clusters; know the effect of cluster division; and language toponymy efforts in the promotion of tourism in old cities in Muntok and Belinyu.

\section{City Identity and Herritage Development}

City identity is a mental image that is formed from the biological rhythms of certain places and spaces that reflect time (sense of time), which is grown from within the root of social, economic, cultural and urban society itself (Lynch, 1972: 25)

Identity is a condition when someone is able to recognize or recall (memory) a place that has a difference with another place because it has character and uniqueness. Identity is a very important basic thing. This is because identity is something that is used to recognize, distinguish a place from another place. According to Lynch (1960) to be able to understand the identity of a city first to understand its image. The image of a city that is easy to imagine (has imagination) and easily brings an impression (having legibility) will be easily identified. City identity can be physical and nonphysical (Suwarno, 1989). The ability to capture city identity is very subjective, depends on the observer, which is visually interesting / imageable (clear, legible, or visible) and easy to remember and unique to be used as regional identity.

\section{The Concept of Social Mapping}

Social mapping is one of the concepts that aims to identify and describe the community systematically 
BERUMPUIN

P-ISSN 2622-8831

Berumpun Journal: An International Journal of Social, Politics and Humanities Vol. 2 No. 1 March 2019

which involves collecting data and information about the community and social problems that occur in people's lives. Referring to Netting, Kettner and McMurtry (1993), social mapping can be referred to as social profiling or "making a profile of a community". Besides that social mapping can also be referred to as an approach by carrying out a development to the community. The main principle for social practitioners in conducting social mapping is that it helps in gathering as much information as possible in a specific area specifically that can be used as material to make the best decisions. In addition to using the concept of social mapping, this research uses the concept of collective memory as a concept that sees real social experiences that give rise to memories of an event or history. According to Halbwachs, collective memory tries to give packaging in this research related to the potential of the old city which raises a collective memory for a group of people, especially in the people of Muntok City and Belinyu City.

\section{Language Toponymy Concept}

On several occasions several stories are often presented about the origin of an area, place, symbol, building, and other markers. This is part of making toponymy. Toponym is the name of the geography closely related to the existence of language. Giving the name of geography in Indonesia is certainly closely related to the use of Indonesian and Regional Languages, so the role of Language is the key to the application of toponymy writing rules (Perdana: 2017).

According to Rais et al. (2008) toponym is interpreted literally as the place name on earth ("topos" is "place" or "surface" like topography which is a description of the surface and "nym" is the name). Limits are more clearly stated by Bishop et al (2011) who define toponymy as a study of places based on historical and geographical information, such as: mountains, rivers, forests, and cities. Kamonkarn et al (2008) revealed that toponymy is a language phenomenon in a landscape that occurs from the local culture, language, history, and environment of each region.

\section{METHOD}

The method used in this research is descriptive qualitative research method with social mapping techniques. According to Slamet (2006: 7) explains that descriptive qualitative research is a research method used to describe various social phenomena that occur in the community in order to provide a more detailed explanation related to the social activities studied. The location used by researchers to retrieve this research data is the City of Belinyu and Muntok Districts. Determination of informants is done by using purposive sampling technique. Data collection techniques are done by collecting secondary data and primary data. Primary data consists of in-depth interviews and participant observation.

\section{DISCUSSION}

\section{Kota tua Muntok}

In general, the settlements in the city of Muntok consist of three clusters divided by ethnic groups, namely Malay, Chinese and European. 
BERUMPUIN

P-ISSN 2622-8831

Berumpun Journal: An International Journal of Social, Politics and Humanities Vol. 2 No. 1 March 2019

Geographically, Malay and Chinese clusters are located on the coast; while the European cluster is located north of the two clusters and is further away from the coast. The types of archaeological remains in the three clusters can be divided into four, namely religious buildings, residential buildings, public buildings and defense buildings. Based on its function religious buildings consist of mosques, tombs and churches; residential buildings in the form of houses; public buildings in the form of schools, resting offices, prisons and lighthouses while defense buildings in the form of fortifications.

During the colonial period Muntok continued to function as the center of government, as evidenced by the placement of a resident, who was in charge of colonial tin trade. Until 1912 the Bangka Resident, in addition to him the holder of government authority, also concurrently responsible for tin mining with a place of residence at Muntok. In 1912 the government center was moved to Pngkalpinang, while Muntok was made a tin exploration center.

In the study of urban growth, there are three phases that are often used in dividing cities based on their growth period, namely the early, colonial and modern periods. Based on the analysis of the map of Muntok city, it is known that the city of Muntok was a city that grew in the colonial period. This is marked by the existence of European clusters as the center of power. In addition, the city of Muntok in the colonial period also functioned as a center for administration and the economy, where residents acted as responsible for government and tin mining.

According to P.J.M.Nas, one characteristic of a colonial city is the separation of population groups based on their ethnic background, so that in general in a colonial city there are three cultural nuances namely local culture, Chinese and European. In the case of the city of Muntok, these three nuances are clearly seen. The results of this study indicate that in the city of Muntok there are at least four groups of settlements which can be divided based on ethnic groups namely Malay, Chinese, European and Arabic.

\section{Muntok Tourism Potential Mapping West Bangka Regency}

Tourism potential is a part that is considered very meaningful if preserved and maintained, will produce opportunities to improve the regional economy. Based on the types of tourism, there are several types of tourism potential that develop in Muntok.

\section{Table 3.3. Tourism Potential}

\begin{tabular}{|c|c|c|}
\hline No. & $\begin{array}{l}\text { Type of } \\
\text { tourism }\end{array}$ & Information \\
\hline 1. & $\begin{array}{l}\text { Religious } \\
\text { Tourism }\end{array}$ & $\begin{array}{l}\text { Jami' Mosque and Kung Fuk } \\
\text { Miaw Temple }\end{array}$ \\
\hline 2. & $\begin{array}{l}\text { Beach } \\
\text { Tourism }\end{array}$ & $\begin{array}{l}\text { Tanjung Kalian Beach, Batu } \\
\text { Rakit Beach dan Tanjung Ular } \\
\text { Beach }\end{array}$ \\
\hline 3. & $\begin{array}{l}\text { Culinary } \\
\text { Tourism }\end{array}$ & $\begin{array}{l}\text { Otak-otak, pempek udang, } \\
\text { kerupuk siput gunggung, Terasi } \\
\text { Udang, Rusip, lempah darat, } \\
\text { Lempah Kuning and various } \\
\text { traditional cakes }\end{array}$ \\
\hline 4. & $\begin{array}{l}\text { Historical } \\
\text { Tourism }\end{array}$ & $\begin{array}{l}\text { Menumbing Mountain, } \\
\text { Dermaga, Batu Balai, Rumah } \\
\text { Mayor, Pesanggrahan Wisma } \\
\text { Ranggam, Pesanggrahan } \\
\text { Menumbing dan Museum } \\
\text { Timah Indonesia }\end{array}$ \\
\hline
\end{tabular}


BERUIMPUIN

P-ISSN 2622-8831

Berumpun Journal: An International Journal of Social, Politics and Humanities Vol. 2 No. 1 March 2019

\section{Source; 2016 Civil Society Population Record}

\section{Kota tua Belinyu}

Belinyu has its own distinctiveness in terms of seafood from Bangka. This is because Belinyu is located in the northern part of Bangka Island which borders the Natuna Sea and Teluk Kelabat waters. Belinyu is one of the old cities that is quite familiar among the people, especially the characteristic of Belinyu city itself, which is culinary tourism in the city such as brains and crackers / kemplang belinyu. Panggang Crispy Cracker, Getas Crackers (Kletek / Kretek), Calamari Crispy Cracker, Shrimp Crispy Cracker, Empek-empek, brains, kricu, temilok, rusip, kecalok and so on are typical foods that are famous for delicious and often used as souvenirs or souvenirs is a snack made from all-round fish which is a product

of the sea which has been processed into souvenirs from the city of Belinyu.

Kelenteng Road or commonly

called Kampung Kelenteng, or Kampung Tengah, is an area where Belinyu's typical crackers and souvenirs are sold. Not only shopping for souvenirs offered at this place, but tourists can also see the manufacturing activities. What is unique about this region is the mixture of neighboring life that is interwoven well between the local indigenous people and the Chinese community that was formerly brought by the Dutch colonizers to the island as miners. Apart from that, in Kampung Tengah there are large old temples and mosques which are one of the oldest mosques in the city. The houses in this village which are inhabited by Malay natives and ethnic
Chinese have an architectural resemblance, which is in the form of a vertical storied stilt house and carved ornaments typical of Malay and Chinese.

The name Kampung Tengah, like most Malay villages, was originally to identify areas that had large mosques as "village centers" or "main villages". By Malays, the center of the village is called "Kampung Tengah", so that the name is attached to this day. The Belinyu community also often calls it Kelenteng Village, because it is synonymous with the existence of hundreds of years old temples that have become an icon for their society. Many tourists visit the temple as a typical tourist destination and must be visited.

The existing social conditions did not create a difference between indigenous Malays and Chinese who were one of the local wisdom of the Belinyu community. All get the same place and rights, so the title of a village uses both cultural icons. Visiting Central Kampung is very easy because it is located not far from downtown Belinyu. If you enter the downtown area of Belinyu and pass Gadjah Mada Road, past the left lane, you will find several typical large wooden houses. Walking along Central Kampung can be started from the Jami Mosque 'which is a large mosque which is often used as a place for organizing religious activities. After that, you can stop at traditional warungs to enjoy typical Belinyu food, then see the Fuk Tet Che Temple which is still used as a place of worship. Furthermore, you can go to the local souvenir shops and other typical Bangka while buying souvenirs to take home is a characteristic of tourists visiting Belinyu City. 
BERUMPUIN

P-ISSN 2622-8831

Berumpun Journal: An International Journal of Social, Politics and Humanities Vol. 2 No. 1 March 2019

\section{Muntok Tourism Potential Mapping West Bangka Regency}

Tourism potential that is considered very meaningful if preserved and maintained will produce opportunities to improve the regional economy. Based on the types of tourism, there are several kinds of tourism potential that develop in Belinyu. Various tours can be categorized using table 3.4 below, as follows

\section{Table 3.4. Tourism Potential}

\begin{tabular}{|c|c|c|}
\hline No. & $\begin{array}{l}\text { Type of } \\
\text { Tourism }\end{array}$ & Information \\
\hline 1. & $\begin{array}{l}\text { Religious } \\
\text { Tourism }\end{array}$ & $\begin{array}{l}\text { Jami' Mosque dan Parit } 14 \text { Temple, } \\
\text { Panji Temple, Fuk Tet Miao, } \\
\text { Toappekong, Fuk Tet Che }\end{array}$ \\
\hline 2. & $\begin{array}{l}\text { Beach } \\
\text { Tourism }\end{array}$ & $\begin{array}{l}\text { Penyusuk Beach, Batu Dinding } \\
\text { Beach, Remodong, Putat, Putri } \\
\text { Island, Lampu Tanjung Ruh Island, } \\
\text { Tengkalat, Phak Kak Liang }\end{array}$ \\
\hline 3. & $\begin{array}{l}\text { Culinary } \\
\text { Tourism }\end{array}$ & $\begin{array}{l}\text { Otak-otak, pempek udang, pempek } \\
\text { cumi, shrimp crispy cracker, calamari } \\
\text { crispy cracker, siput gunggung, } \\
\text { Terasi Udang, Rusip, lempah darat, } \\
\text { Lempah Kuning dan various types of } \\
\text { traditional cake. }\end{array}$ \\
\hline 4. & $\begin{array}{l}\text { Historical } \\
\text { Tourism }\end{array}$ & $\begin{array}{l}\text { Kapitan Bong Graveyard, Benteng } \\
\text { Kuto Panji, Goa Maria, Kampung } \\
\text { Gedong. }\end{array}$ \\
\hline
\end{tabular}

Source; processed field data (primary data)

\section{Collective Memory Analysis of the Old City of Muntok and Belinyu}

Memory is something that appears responsively when memories or past (history) are present in the mind through social processes or stories from a history. History is a trace of the past that must be preserved and remembered and cared for its existence (existence), this is a manifestation of the form of love for the path that the masalalu has. However, in reality social memory is not only felt in individuals, but can occur in groups, communities or communities that have real social experience originating from a long historical process. The statement is referred to as collective memory, that collective memory is a social experience based on the existence of a group of social memories both explicitly and implicitly from different levels of memory from each of the good experiences of memory of an event, place, building and so on.

This study seeks to examine the collective memory of a place that has historical value. In addition to having the historical value of the place that is the focus of this research study is a place that has tourism potential, namely the old city. The old city is a stub city area that was formerly built by colonists, especially the Dutch who colonized Indonesia as a trade center in Asia, especially on Bangka Island. Muntok and Belinyu are two old cities in Indonesia, especially in the Bangka Belitung Islands Province. Based on the social mapping, the two old cities have their own tourism potential. Although both are called old city icons, however, the conditions of these two cities have differences, especially from 
the side of the building and tourism potential.

The old city building of Muntok and Belinyu is one of the buildings that gave rise to a collective memory for the people of Bangka Belitung, especially the people of Muntok and Belinyu. The old town of Muntok and Belinyu have their own historical values. Muntok is one of the old cities which at that time was built during the reign of Sultan Mahmud Badarudin Jayawikrama where at that time Muntok was made the center of government and affairs of tin ore mining in Muntok in the Dutch era. In addition to the Netherlands, Britain also contributed to the history of the city of Muntok, where at that time the British established an arsenal known as the yellow warehouse. The Bangka tin museum, which is currently one of the historical tourist objects of the city of Muntok, used to be the center of government given the name Hoofdbureau Banka Tin Winning Bedriffdan. In addition, the pier which is now the old port of muntok used to have historical value, where the port was built as an effort from the Dutch government to make it easier for large Dutch ships to dock at Muntok.

The emergence of collective memory can also be found in wellmaintained buildings and creates a nuance of tolerance that is so tight between the two buildings in the city of Muntok. The building is better known as the Jami Mosque and the Fuk Miau Kong Temple. The two old buildings are close together and side by side reflecting the tolerance built in the City of Muntok. These two old buildings are icons of Tanjung Village. Both of these buildings were built in the era of the 18 th century. These two adjoining buildings are a place for visiting tourists. The majority of tourists visiting this place on the grounds that they are interested and feel the religious tolerance built in Muntok City is very high, this is evidenced through the building structure of each mosque and pagoda building that collaborates with each other and has historical value.

In addition, old buildings that are often the place for tourist visits, namely Pesanggrahan Ranggam. Pesanggrahan Ranggam is one of the old buildings that has historical and tourist value. This building is one proof that the leaders of the proclamation have experienced difficult times on Bangka Island. The building was built by the Dutch and was used as a place of exile for the first time Prince Pakuningprang was exiled in 1897, besides Bung Karno, Mr. Moch Roem, H. Agus Salim, and Mr. Ali Sastroamidjojo. When tourists visit they feel and appear memories of invaders who colonized Indonesia. Visitors who visit will be carried away by an atmosphere which reminds the proclamation figures to be exiled and struggle with all the limited conditions at that time on Bangka Island. However, at present the old building is used as a tourist destination and provincial government meeting, based on data obtained in the field, namely the caretaker or historian explains that this place is most visited and in demand by tourists, tourists are both from inside and outside Indonesia, like from Brazil. No less interesting is that the collective memory spaces were also present in one of the old buildings in Soekarno's and friend's stopover in Menumbing. Menumbing is also one of the old city buildings that has a 
historical value where Soekarno once isolated himself even though it was only one day, but the building has such a complex historical value.

Furthermore, the City of Belinyu, Kota Belinyu is also no less interesting than the City of Muntok. Belinyu is one of the icons of the old city that has quite interesting historical value. The city of Belinyu is a city where the buildings where they live are still Chinese in origin and are of historical value. Kampong Gedong, located in Kuto Panji village, is a village where the majority of Chinese people migrated from China in the Dutch colonial era. They were descended from Chinese tin miners. Usually visiting tourists never forget to visit Kampong Gedong. The reason tourists visit is because the original architectural building reminds us of a traumatic memory to the invaders. This memory is a collective memory that directly arises and reminds of a certain event or event that left an impression on a group of people. Especially the memory of the architecture that is still original without any modification and the environment accompanied by the sound of birds adds to the nuances of being more valuable. Furthermore, Kuto Panji Fortress is one of the old buildings that presents its own collective memory nuance, not only from its historical value, but the building that looks old and the architecture of buildings filled with ancient writings makes it a building that has unique and historic characteristics. Besides that it is adjacent to one of the temples, Kuto Panji is a place where there is a commercial process or port of sailing ships and also a tin smelter in the Dutch era. The building has begun to be modified by the managers of the temple and Kuto Panji Fortress, on vacant land used as a tourist spot for visitors in addition to enjoying the beauty of the temple and Kuto Panji Fortress, tourists can enjoy artificial tours provided by the managers. In addition, this place is also used as a place of prayer to seize the customs of the Chinese community.

\section{Toponymy as a Tourism Promotion Effort}

\section{A. The Origins of Kota Belinyu}

In ancient times, Bangka Island had no paddy fields, but only field rice fields or terrestrial rice. In the past, the people of the Sekak tribe or sea tribe in the Belinyu and Bangka islands privileged Belinjo food. This food is special because it is usually eaten during the ritual ceremony of Buang Jong whose center is at Tanjung $\mathrm{Ru}$ Beach, Teluk Kelabat. At that time the results of catching sea products such as sea cucumbers or sea cucumbers, fish, crabs, shellfish, seaweed are usually exchanged for terrestrial rice, and if there is no terrestrial rice then they replace it with this Belinjo. The boiled Belinjo fruit at that time can be used as a staple meal when rice fields fail to harvest. Now, Belinjo is used as food for chips, which are chips.

\section{B. The Origin of Kota Muntok}

source says that the name Muntok was taken from a British Governor-General based in Tumasik, now Singapore, namely Lord Minto. Another source said that Muntok originated when Prince Jayawikrama ascended the throne as Sultan Mahmud Badarudin I who had the Sultan's first wife named Zamnah who came from Johor who was then allowed to live in 
BERUIMPUIN

P-ISSN 2622-8831

Berumpun Journal: An International Journal of Social, Politics and Humanities Vol. 2 No. 1 March 2019

Bangka. The wife saw from Tanjung Sungsang, the plains at the mouth of the Musi River on Sumatra Island which were considered habitable. The wife said "Amun tok, if that is the right place". More or less the princess said. About that the origin of the City of Muntok, which was then recited by the local community, became recited by the local community as Mentok.

\section{CONCLUSION}

This research is still searching for more valid data to support writing about the origin of a city as seen from the toponymy approach. Social mapping is a measure of the area where the old urban areas are focused, which will be described as toponymes supported by community collective memory data symbolized by several inscriptions, monuments, and buildings in the museum and / or on the sides of the road.

As a cultural heritage, archeological heritage in the City of Muntok should be protected and preserved because ancient buildings contain important values both in terms of history, science, culture and socio- economic. Regarding utilization, some archaeological remains in the city of Muntok can be used as objects of research and cultural attractions. In the utilization in the field of science archeological remains in the city of Muntok can be used as objects of research in other sciences such as architecture, anthropology, history and sociology. As for the use of tourism, these relics are tourist objects that visitors can see a history of the growth and development of a city known for its tin.

\section{REFERENCES}

Bungin, Burhan. 2003. Analisis Data Kualitatif. Jakarta: Rajawali Pers.

Cipta, Hendra. 2017. Kawasan Ekonomi Khusus dan Potensi Pariwisata Provinsi Kepulauan Bangka Belitung. Kawasan Ekonomi Khusus dan Pariwisata. Jurnal Tawshiyah volume 12 no. 1 Tahun 2017.

Kadarwati, Atik. 2008. Potensi dan Pengembangan Wisata Kota Lama Semarang sebagai Daya Tarik Wisata di Semarang. 
Kamonkarn, Ambua., dkk. (2008). Toponymy, Landform and Geographical Analysis that Influence the Community's Cultural Economics and EcoTourism: Case Study in the District of Muang, Mae Chan, Mae Sai, Chiang Sean, Chiang Khong, Wieng Kaen, and Teoung, Chiangrai.

Lynch, Kevin 1972. What Time is this Place?. MIT Press. ISBN 0-262-12061-5.

Lynch, Kevin. 1960. The Image of the City. Cambridge MA: MIT Press. OL 5795447M

Netting, F. Ellen, Peter M. Kettner dan Steven L. McMurtry (1993), Social Work Macro Practice, New York: Longman

Perdana, Aji Putra. 2017. "Toponim, Sejauh Mana Peran Bahasa dalam Penamaan Unsur Geografi”. Detik.com

Refni Yulia, Meri Erawati, Gusti Asman, Noriyasman. 2017. Revitalisasi Kawasan Kota Tua Padang Sebagai Salah Satu Alternati Wisata Sejarah di Kota Padang. Jurnal Bakaba. Volume 6, Nomor 2, Desember 2017: 17-23

Slamet, Yulius. 2006. Metode Penelitian Sosial. Surakarta: UNS Press.

Soeprapto dan Sumarah, Sri Rahayu. 2002. Metode Penelitian Kualitatif. Jakarta: Universitas Terbuka.

Sugiyono. 2007. Memahami Penelitian Kualitatif. Bandung: Alfabeta.

Yulianto, Agus. 2018. Strategi dan Arah Kebijakan Pengembangan Daerah Kepulauan. Republika Online. http://www.republika.co.id/berita/jurnalismewarga/wacana/18/01/09/p2aks3396-strategi-dan-arah-kebijakanpengembangan-daerah-kepulauan.

Pemprov Kepulauan Bangka Belitung. (2018). 12 Oktober 2018. http://www.visitbangkabelitung.com/content/kampung-tengah-belinyu. 